\title{
PLANIRANJE RADOVA MONTAŽE ČELIČNE KONSTRUKCIJE KOD IZVOĐENJA PTC PORTANOVA U OSIJEKU
}

\author{
Maja Savić \\ Sveučilište J. J. Strossmayera u Osijeku, Građevinski fakultet Osijek, student \\ Ivan Ćurić \\ Sveučilište J. J. Strossmayera u Osijeku, Građevinski fakultet Osijek, student \\ Zlata Dolaček-Alduk \\ Sveučilište J. J. Strossmayera u Osijeku, Građevinski fakultet Osijek, doc.dr.sc.
}

Sažetak: Izvođenje montažnih radova zahtijeva opsežne pripreme i detaljnu analizu ograničavajućih faktora u projektu. Kako izvođenje ovih radova uključuje primjenu skupih dizalica, jedan od ciljeva pripremnih radova treba biti njihova optimalna primjena, kako u vremenu tako i u pogledu njihove nosivosti. Optimalna primjena postiže se izradom detaljnog plana montaže. U radu se daje pregled varijanti montaže čelične konstukcije kod izvođenja Poslovno-trgovačkog centra Portanova u Osijeku.

Ključne riječi: tehnologija montaže, planiranje montažnih radova, čelična konstrukcija, plan montaže

\section{WORK PLANNING OF STEEL STRUCTURE ASSEMBY DURING THE CONSTRUCTION OF PTC PORTANOVA IN OSIJEK}

\begin{abstract}
Assembly work performance requires extensive preparation and detailed analysis of the limiting factors in the project. To perform these works involves the application of expensive crane one of the goals of preparatory work has to be their optimal application in time and in terms of their capacity. Optimal use is achieved by creating detail assembly plan. The paper provides an overview of assembly variants of steel construction in the construction of shopping mall Portanova in Osijek.
\end{abstract}

Key words: assembly technology, assembly works planning, steel construction, assembly plan 


\section{Općenito}

Jedna od glavnih karakteristika spregnutih konstrukcija je optimalizacija iskorištenja pozitivnih svojstava primijenjenih materijala. Kod spregnuth konstrukcija čelik-beton koriste se prednosti i betonskih i čeličnih konstrukcija. Kod ovih konstrukcija u vlačnoj zoni koriste se čelični nosači, a u tlačnoj zoni betonske ploče. Spregnute konstrukcije ekonomične su za srednje i velike raspone. Mogućnost premošćivanja velikih raspona omogućuje fleksibilnost u oblikovanju konstrukcije kao i slobodu oblikovanja unutarnjeg prostora građevine [5].

Montaža čelične konstrukcije kod gradnje Poslovno-trgovačkog centra Protanova Osijek samo je jedan segment kompleksnog procesa izvedbe građevine. Zbog toga projekt montaže čelične konstrukcije zahtijeva koordinirani rad svih sudionika u gradnji - usklađenost s projektnom dokumentacijom, izrađenom shemom uređenja gradilišta, dinamičkim planom izvođenja radova, dinamikom korištenja privremenih objekata, osiguravanje manipulativnog prostora na gradilištu za privremeni smještaj elemenata i sklopova konstrukcije prije montaže, korištenje razvoda električne energije i ljudskih resursa na gradilištu [6].

Izrada projekta organizacije građenja kod izvođenja ovog projekta podrazumijeva prethodno proučavanje svih uvjeta u kojima će se izvoditi radovi, što je preduvjet da bi se oni mogli izvesti racionalno. Nakon proučavanja uvjeta izvođenja radova, potrebno je na bazi detaljne analize odabrati optimalnu metodu i to za svaku vrstu radova. Usporedo s proučavanjem i izborom metoda, treba izvršiti i podjelu rada po fazama kako bi se sagledao redoslijed izvođenja radova, kao i njihova međusobna zavisnost. Nakon toga slijedi izbor tehnologije te način i redoslijed izvođenja aktivnosti [7].

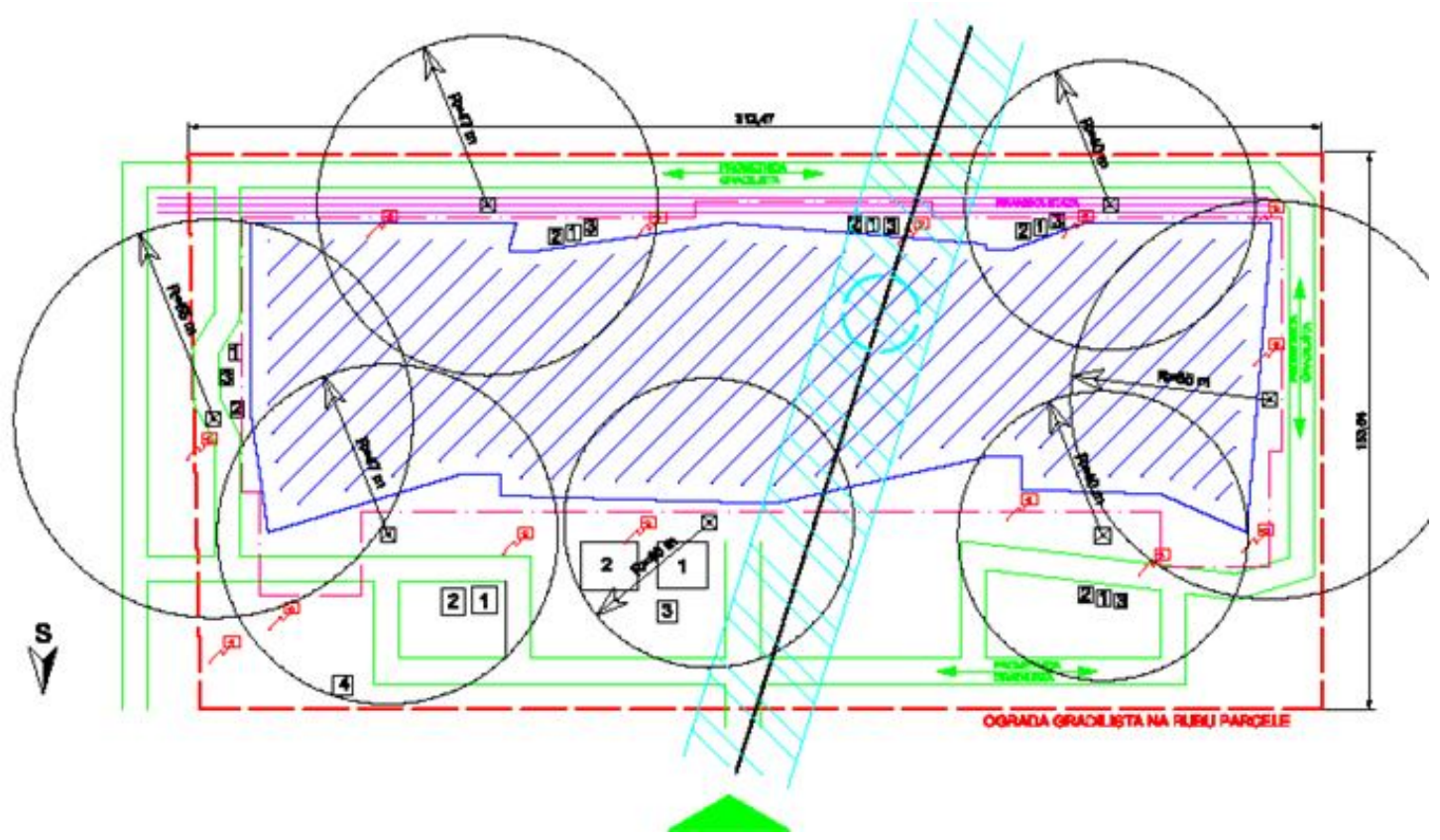

Slika 1 - Shema uređenja gradilišta PTC Portanova Osijek [3]

Preduvjet za racinalno izvođenje radova je izrada odgovarajućeg projekta organizacije građenja koji podrazumijeva prethodno proučavanje svih uvjeta u kojima će se izvoditi radovi te nakon toga analizu mogućih varijanti izvođenja za sve vrste radova. Sastavni dio ovog projekta je i izrada sheme uređenja gradilišta (slika 1). Izrađena shema rezultat je proučavanja svih utjecajnih faktora tijekom izrade projekta. U njoj su naznačeni svi objekti iz područja privremenih radova: privremene prometnice, privremena naselja i svi objekti gradilišta sa svrhom dobivanja potpunog uvida u lokaciju i raspored kapaciteta potrebnih za izvođenje objekta (najpovoljniji razmještaj svih objekata i kapaciteta), kao i njhova međusobna veza (povezanost) i uvjetovanost u vezi s tehnologijom građenja. Cilj izrade sheme uređenja gradilišta je osigurati takav raspored resursa koji će omogućiti minimalne proizvodne troškove. Osobito je važno racionalno rješenje unutrašnjeg transporta i povezivanje gradilišta s vanjskim prometnicama, te racionalno povezivanje s energetskim izvorima $[3,6]$. 


\section{Tehnološke značajke izvođenja spregnutih konstrukcija}

Jedna od bitnih značajki spregnutih konstrukcija je složenost njihove izvedbe. Zbog složenosti izvođenja neophodna je tehnička i kadrovska opremljenost, kao i iskustvo u radu. Važna je dobra interakcija i razumijevanje između projektanta, proizvođača čelične konstrukcije i izvođača radova. Osobito je važan redoslijed izvođenja radova kako bi se ostvarili planirani učinci spregnutih presjeka. Redoslijed izvođenja radova kod izvođenja spregnutih konstrukcija mora biti usklađen sa zahtjevima iz projektne dokumentacije.

\subsection{Izvođenje betonskih radova}

Betonski radovi izvode se u skladu s projektom betonske konstrukcije, uputama proizvođača za ugradnju i uporabu građevnih proizvoda i zahtjevima Tehničkog propisa za betonske konstrukcije. Sukladno projektu konstrukcije, izvođač radova izrađuje Plan kvalitete izvedbe betonske konstrukcije koji, između ostalog, obuhvaća i Plan betoniranja i Plan uzorkovanja i ispitivanja [1].

Dokumentacija izvedbe betonske konstrukcije sadržajno obuhvaća:

- izvore materijala, potvrde o sukladnosti i dobavljačeve izjave o sukladnosti

- $\quad$ način provedbe promjena u izvedbi pojedinih radova

- plan kvalitete i nadzora izvođenja betonske konstrukcije

- $\quad$ nacrt izvedenog stanja, uključivo i ugrađene predgotovljene elemente

- zapise o promjenama u projektnoj specifikaciji

- zapise o kontroli geometrijskih odstupanja.

\subsection{Montaža čelične konstrukcije}

Montaža čelične konstrukcije izvodi se prema Projektu montaže čelične konstrukcije. Projekt montaže radi izvođač radova i dostavlja na uvid projektantu konstrukcije i nadzornom inženjeru. Sadržajno, projekt montaže obuhvaća [4]:

- $\quad$ opis i redoslijed izvođenja elemenata kod montaže

- uvjete montaže za pojedine elemente konstrukcije

- dinamički plan montaže

- $\quad$ popis potrebne opreme i mehanizacije

- $\quad$ shemu montaže s putanjama kretanja transportnih sredstava i mehanizacije

- mjere zaštite na radu

- $\quad$ mjere zaštite od požara.

Kod montaže čelične konstrukcije potrebno je pridržavati se sljedećih principa [4]:

- radove trebaju izvoditi radnici obučeni za montažne radove (bravari, zavarivači, montažeri obučeni za rad na visini)

- istovar iz transportnog vozila obavlja se prema točno utvrđenom redoslijedu, na mjestu u neposrednoj blizini montaže kako bi se olakšao i ubrzao rad na montaži konstrukcije

- montaža se obavlja prema utvrđenom redoslijedu iz plana montaže, kako ne bi bila ugrožena stabilnost građevine tijekom gradnje

- na gradilištu je potrebno osigurati dovoljan broj projektom predviđenih spojenih sredstava na mjestu montaže

- tijekom montaže treba težiti da se dizalica što manje pomiče tijekom procesa montaže, odnosno da se iz jednog položaja podigne i prenese što više elemenata

- u svakom trenutku izvođenja radova mora biti osigurana stabilnost i geometrija građevine pa je potrebno prije početka montaže izvršiti sva neophodna geodetska mjerenja

- montažu treba organizirati na način da se nesmetano, sukcesivno i kontinuirano završavaju određene cjeline građevine. 


\section{Tehnički opis spregnute konstrukcije PTC Portanova u Osijeku}

Za konstrukcijsko rješenje Poslovno-trgovačkog centra Portanova u Osijeku odabrana je monolitna betonska konstrukcija u podrumu i spregnuta konstrukcija na katovima. Za osnovni raster objekta na etažama predviđen je raster $16,20 \times 8,10 \mathrm{~m}$. Kao međukatna konstrukcija predviđena je spregnuta konstrukcija čelik-beton. Nosivu čeličnu konstrukciju raspona 16,20 m čine saćasti I nosači visine $1250 \mathrm{~mm}$ i I nosači visine HEA 320, na međusobnom osnom razmaku od 4,05 m. Betonska ploča je izvedena lijevanjem na licu mjesta u oplati koju čine profilirani limovi Hoesch Additive Floor bez podupiranja i koji ostaju kao trajna oplata [6].

Elementi čelične konstrukcije izrađeni su od vruće-valjanih I i L profila te hladno-oblikovanih cijevi pravokutnog i kvadratnog poprečnog presjeka kvalitete S355JR (slika 2). Pomoćni elementi za montažu I nosača trapeznih limova te moždanika spregnutih greda su kvalitete S235JR. Pozicije se u radionici spajaju u sklopove zavarivanjem koje je određeno klasom izvedbe EXC2 prema HRN EN 1090-2, prema HRN EN ISO 3834. Elementi čelične konstrukcije na gradilištu se spajaju vijcima M20 i M24 (slika 3). Antikorozivna zaštita čelične konstrukcije provodi se bojanjem prema Pravilniku o tehničkim mjerama i uvjetima za zaštitu čelične konstrukcije od korozije.

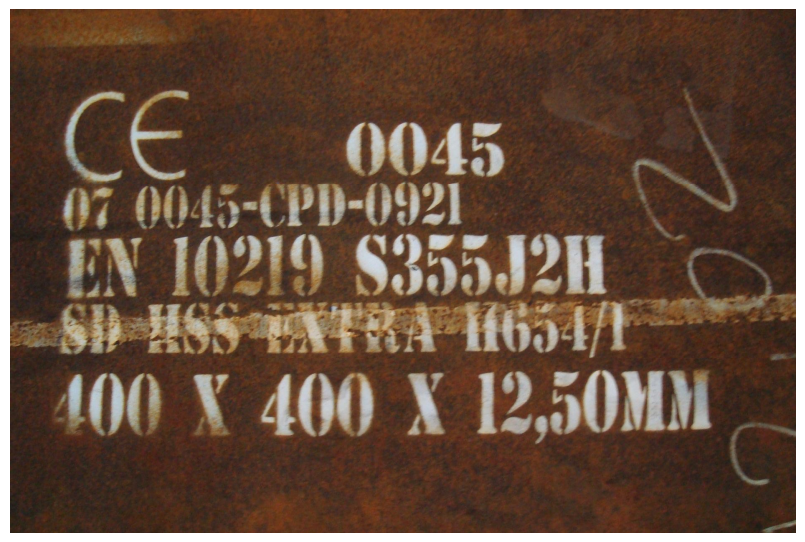

\section{Slika 2 - Oznaka kvalitete čelika za proizvodnju nosača}

Nosive konstrukcije stropova su spregnute ploče sistema Hoesch Additive Floor (slika 4). Visokoprofilirani čelični limovi oslanjaju se na glavne i sekundarne spregnute grede. Ploče se uz betonske zidove u fazi montaže oslanjaju na L-profile. Konstrukcija stropa prizemlja montira se na prethodno izvedene armiranobetonske stupove prizemlja. Na konstrukciju prizemlja postavljaju se pomoćni stupovi koji će ostati unutar betonskih stupova i dijagonale za stabilizaciju koje se prije betoniranja premještaju na drugu dilataciju. Proračun i dimenzioniranje pomoćnih elemenata čelične konstrukcije za fazu montaže provedeno je prema normama EC3.

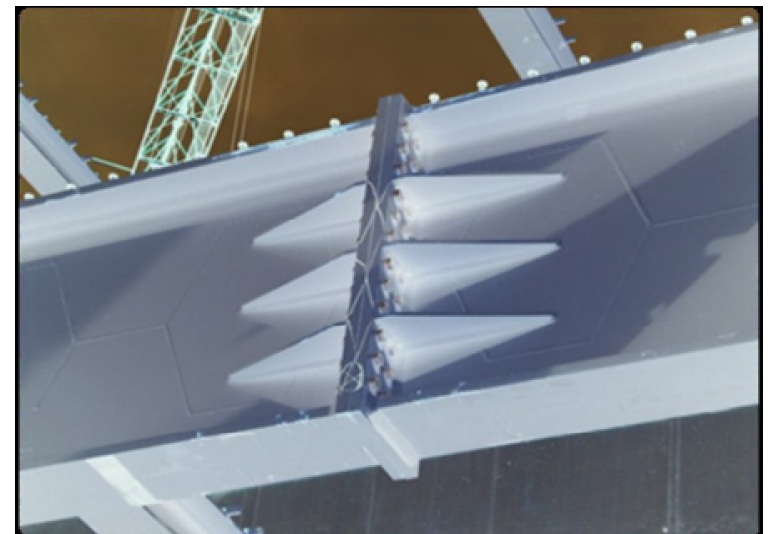

Slika 3 - Detalj spoja vijcima

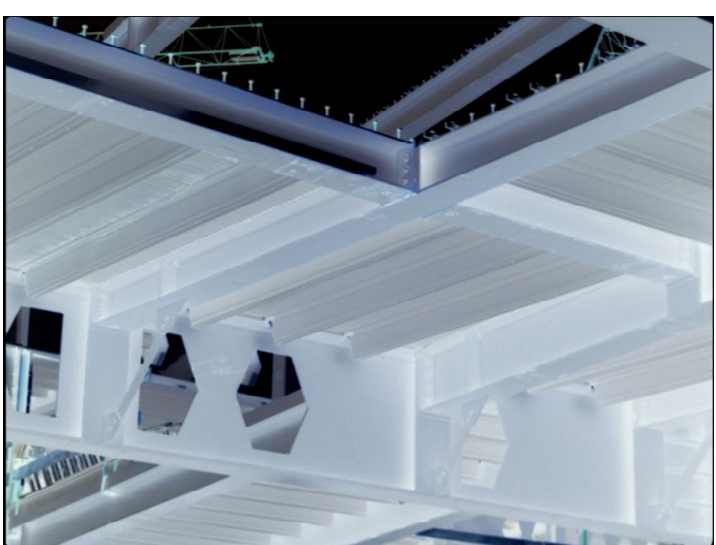

Slika 4 - Pogled na konstrukciju stropa 


\subsection{Skladištenje čelične konstrukcije na skladištu radionice i gradilišta}

Prije same montaže, dijelovi čelične konstrukcije i materijal za čeličnu konstrukciju na gradilištu zaštićuju se od svakog djelovanja koje može prouzročiti oštećenje. Na gradilištu je uređen prostor za prijem konstrukcije i za pripremu montaže. Na skladištu radionice čelična konstrukcije slaže se tako da su ispunjeni sljedeći uvjeti:

- dijelovi konstrukcije ne naliježu na tlo, nego se ona postavlja na podmetače

- razmak između podmetača ili umetaka isključuje pojavu trajnih deformacija

- u uskladištenim dijelovima se ne zadržava voda

- nosači su u pravilu položeni po svojoj većoj dimenziji profila.

Prije otpremanja sa skladišta na montažu, čelična konstrukcija se kontrolira, sortira po pojedinim dijelovima građevine i obilježava prema redoslijedu montaže.

\subsection{Montaža čeličnih elemenata}

Prije transporta i montaže gotovih pozicija, nadzorni inženjer kontrolira i preuzima gotove pozicije. Pri montaži svakog elementa, nadzorni inženjer svojim upisom u građevinski dnevnik dozvoljava rad na predmetnoj poziciji po predočenom planu i dozvoljava eventualnu izmjenu plana montaže ako je to potrebno.

Prije početka montaže nosive čelične konstrukcije, izvedeni su armiranobetonski stupovi prizemlja, rubni zidovi i sve jezgre, uključujući i kružnu rampu, do vrha objekta. Montaža čelične konstrukcije započela je postavljanjem glavnih nosača (saćasti HEM800) u osima x01-X08. Nakon toga montirani su sekundarni nosači u poljima x01-x04 i x05-x08. Polje x04-x05 popunjava se sekundarnim nosačima na kraju, radi kompenzacije dužina nosača. Nakon montaže podliveni su svi ležajevi (oslonci na stupovima i zidovima), a zatim se nastavilo $\mathrm{s}$ montažom pomoćnih stupova i dijagonala. Montaža konstrukcije prvog kata obavljena je istim redoslijedom kao i prizemlje. Po završetku montaže glavne konstrukcije postavljeni su Hoesch trapezni limovi i rubni L-profili uz betonske zidove. Nakon postavljanja čelične konstrukcije dilatacije 1, betonira se ploča iznad prizemlja (slika 5). Postavljanje oplate i betoniranje stupova prvog kata izvedeni su u dvije faze. Prvo su izvedeni oni stupovi koji nisu u sustavu privremene stabilizacije (nemaju dijagonale). Nakon što je beton očvrsnuo i preuzeo ulogu stabilizacije konstrukcije, demontirane su dijagonale i izvedeni ostali armiranobetonski stupovi. Na kraju se betonira ploča stropa prvog kata.

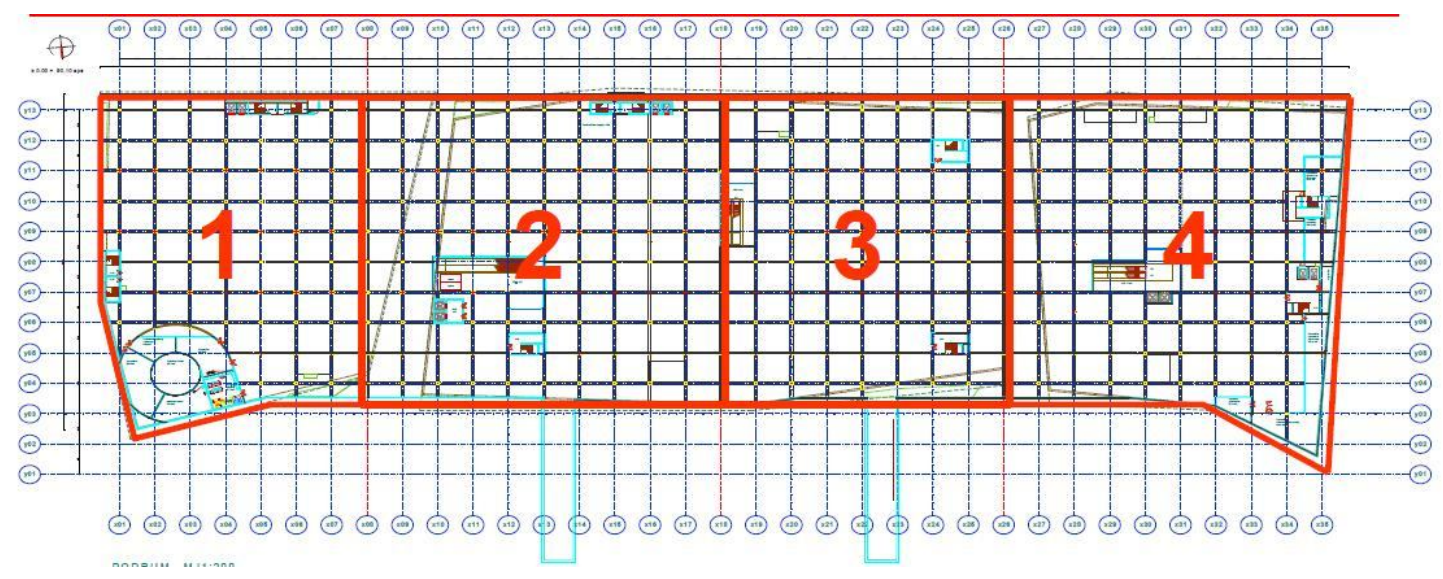

Slika 5 - Shema podjele građevina na dilatacije

Nakon montaže prvog elementa, snimaju se osovinski i visinski položaj svakog elementa. Prije definitivnog učvršćenja geodetski se kontrolira položaj, a rezultati kontrole unose se u zapisnik. Tek nakon utvrđivanja ovih činjenica, može se pristupiti spajanju gornjeg dijela stupa i konstrukcije. Sva dokumentacija pri svakom mjerenju mora se zabilježiti u dnevnik montaže i sačuvati za tehnički prijem konstrukcije. 


\section{Planiranje montaže čelične konstrukcije i potrebna mehanizacija}

Tijekom izvedbe zemljanih radova inženjeri su razvijali različite taktike montaže čelične konstrukcije. Pojedini elementi konstrukcije montirali su se pojedinačno, dok su se u drugom slučaju izrađivali sklopovi od 2 glavna i 2 sekundarna nosača, ukupne težine oko 15 tona. Zbog toga se pojavio problem izbora mehanizacije za montažu i pozicije pristupa stroja građevini tijekom montaže. Inženjeri su tijekom odabira varijante montaže razmatrali tri rješenja od kojih je svako imalo svoje prednosti i nedostatke.

\subsection{Montaža pomoću autodizalice sa stropne ploče}

Prvo moguće rješenje bila je montaža čeličnih nosača pomoću autodizalice (slika 6). Nosači su se trebali montirati pomoću autodizalice na način da autodizalica ulazi na stropnu ploču i s te pozicije podiže teret. Stropnu ploču je trebalo dodatno proračunati/provjeriti na opterećenje montažnog sklopa zajedno s dizalicom koje je iznosilo oko 40 tona. Proračunom je dokazano da ploča nema dovoljnu nosivost za takvo dodatno opterećenje niti uz podupiranje ploče, pa se od ovog rješenja odustalo.

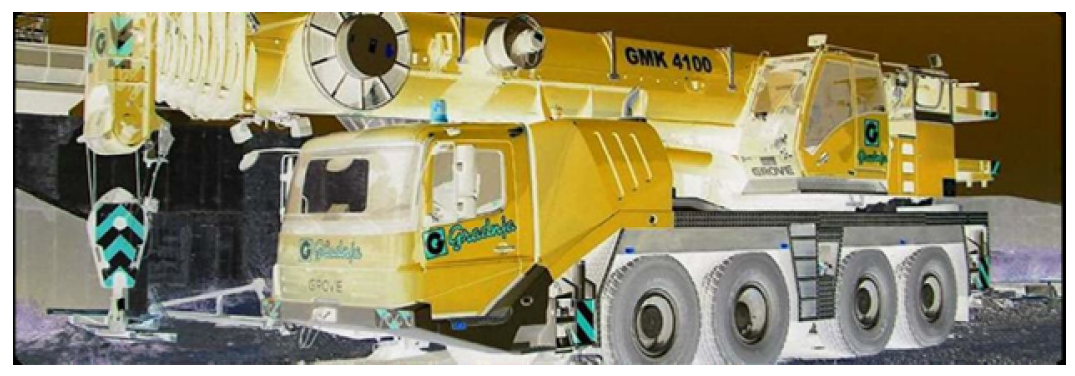

Slika 6 - Autodizalica

Negativne strane ovog rješenja su i problem dovoza dizalice na stropnu ploču, problem rada kranova, manevriranje šlepera koji trebaju pristupiti dizalici, odnosno preklapanje većeg broja aktivnosti na relativno malom prostoru. Jedina pozitivna strana ovog rješenja je cijena rada dizalice - nije potreban najam dizalice jer izvođač radova posjeduje dovoljno takvih dizalica.

Shema uređenja gradilišta za ovakvo rješenje bi se razlikovala od usvojene sheme, jer bi uključivala i putove kretanja dizalica i područje njihovog manevriranja.

\subsection{Montaža autodizalicama pokraj objekta}

Drugo razmatrano rješenje bila je montaža autodizalicama koje neće ulaziti na stropnu ploču, nego će se kretati s južne i sjeverne strane objekta i montirati nosače (slika 1).

Prednost ovog rješenja je također cijena rada, jer se koriste vlastiti resursi i nije potreban najam specijalnih strojeva. Problem ovog rješenja je prostor od samo $10 \mathrm{~m}$ (na najužem dijelu) na južnoj strani objekta, što nije dovoljno za manevriranje dizalice pa time niti montaža nosača u sredini objekta. Objekt je širine $85 \mathrm{~m}$ i ruka dizalice ne može prenositi teret na tu udaljenost. Pristup autodizalice na stropnu ploču nije moguć zbog razloga koji je naveden u točki 4.1 ovog rada. Ovo rješenje je također samo ekonomski najprihvatljivije.

Shema uređenja gradilišta za ovo rješenje sadržavala bi putove kretanja i manevriranja autodizalica, ali samo u području oko objekta.

\subsection{Montaža čelične konstrukcije dizalicom}

Treće rješenje, koje je i usvojeno, jest montaža konstrukcije pomoću dizalice proizvođača Terex, tip Demag cc2200. Izvođač radova ne posjeduje takvu vrstu dizalice pa je ista unajmljena od austrijskog poduzeća Prangl (slika 7). Najam dizalice je znatno povećao troškove građenja - ali je to bilo najučinkovitije rješenje. 


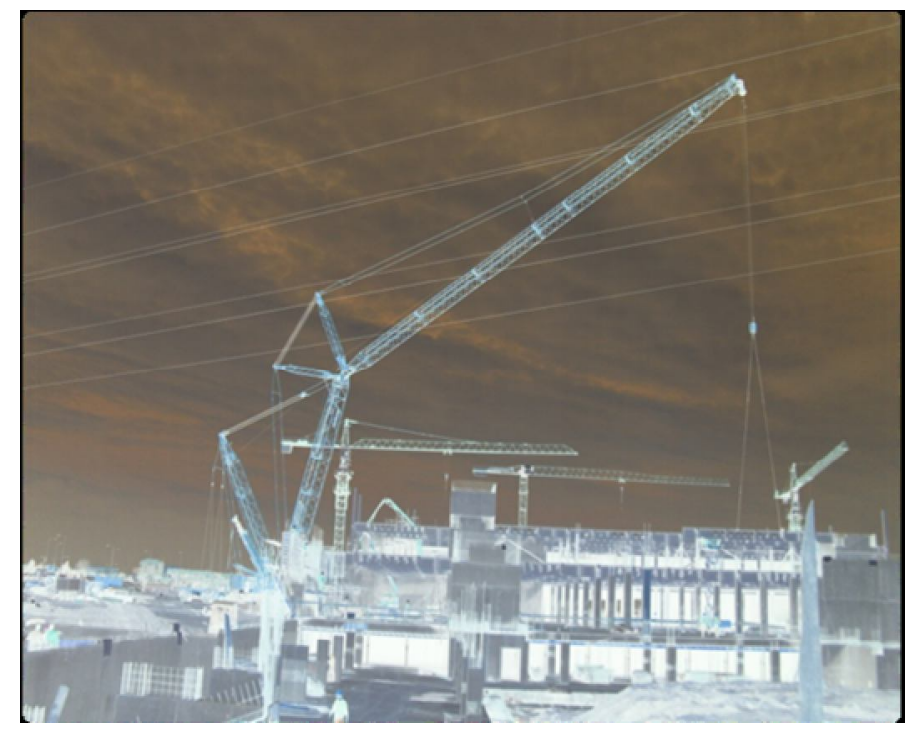

Slika 7 - Prangl dizalica u radu

Ovisno o napredovanju radova, revidirana je i shema uređenja gradilišta. Dizalica se nalazila na sjevernoj strani objekta, jer je samo na toj strani bio dovoljan prostor za manevriranje. Dizalica je, sukladno dinamičkom planu izvođenja radova i planu montaže čelične konstrukcije, na gradilištu bila angažirana od studenog 2009. godine do rujna 2010. godine.

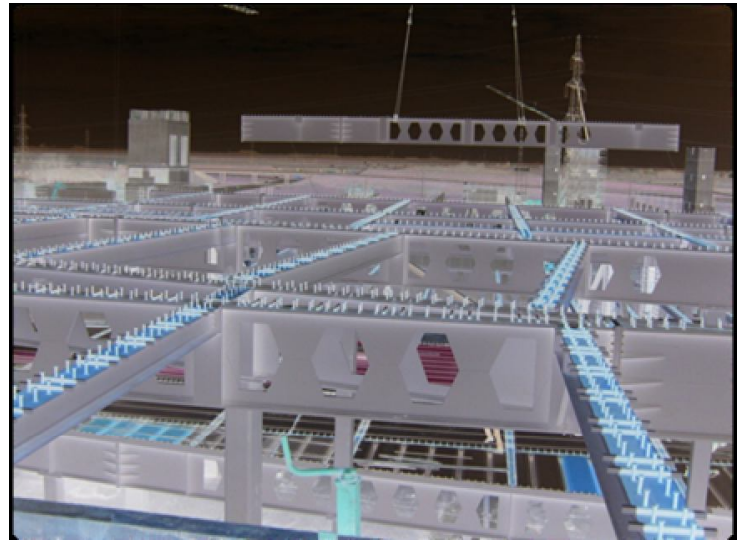

Slika 8 - Montaža pojedinačnih nosača

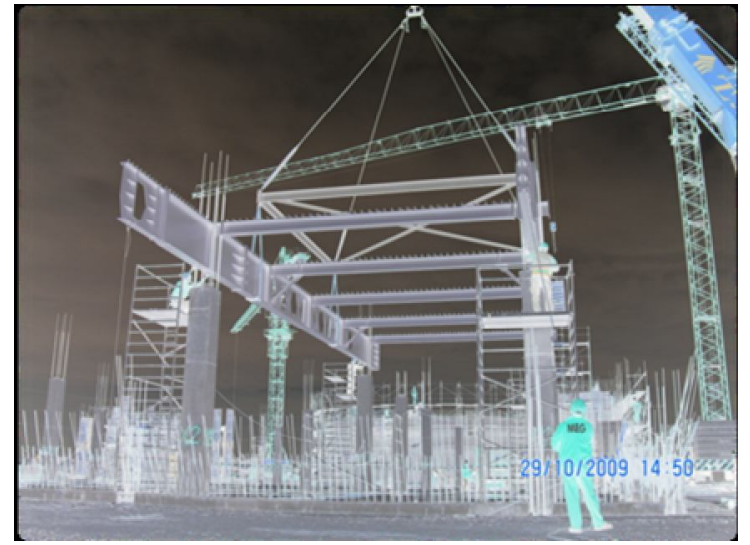

Slika 9 - Montaža sklopa

Po završetku rada dizalica je demontirana pomoću dvije autodizalice. Za prijevoz dizalice bilo je potrebno osigurati 25 kamiona (slika 10).

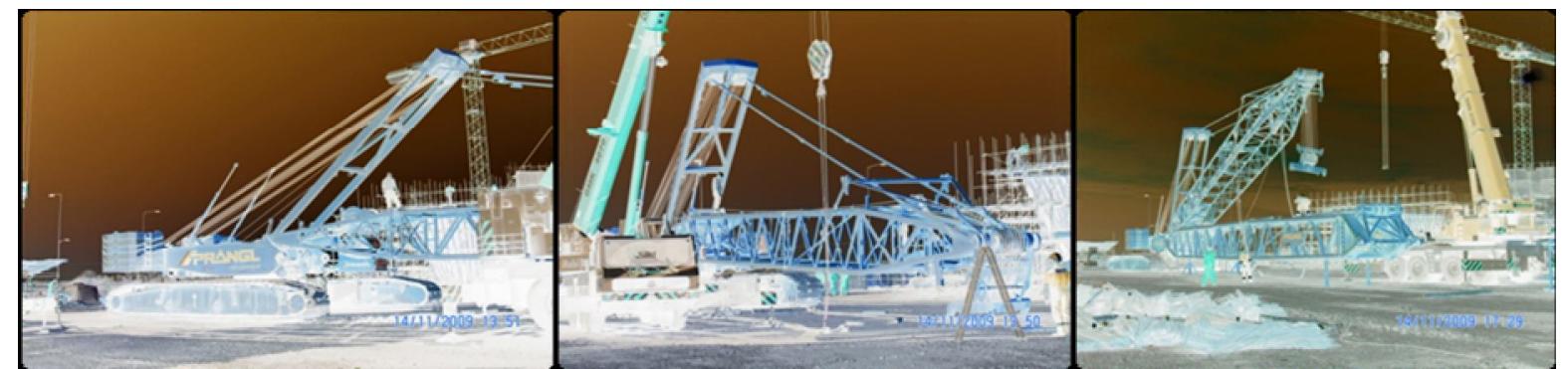

Slika 10 - Demontaža dizalice 


\section{Zaključak}

Za konstrukcijsko rješenje Poslovno-trgovačkog centra Portanova u Osijeku odabrana je monolitna betonska konstrukcija u podrumu i spregnuta konstrukcija na etažama. Montaža čelične konstrukcije kod gradnje Poslovnotrgovačkog centra Protanova Osijek samo je jedan segment kompleksnog procesa izvedbe građevine. Zbog toga projekt montaže čelične konstrukcije zahtijeva koordinirani rad svih sudionika u gradnji - usklađenost $\mathrm{s}$ projektnom dokumentacijom, izrađenom shemom uređenja gradilišta, dinamičkim planom izvođenja radova, dinamikom korištenja privremenih objekata, osiguravanje manipulativnog prostora na gradilištu za privremeni smještaj elemenata i sklopove konstrukcije prije montaže, korištenje razvoda električne energije i ljudskih resursa na gradilištu. Tijekom izvedbe zemljanih radova inženjeri su razvijali taktike montaže čelične konstrukcije te $u$ konačnici odabrali način montaže pomoću dizalice.

Ovakav izbor načina montaže povezan je sa skraćenjem vremena montaže i povećanjem sigurnosti na radu. Odlučujući detalji, osim uvjeta na gradilištu koji utječu na proces montaže, su veza stup-glavni nosač, osiguranje stabilnosti tijekom montaže, odnosno mogućnost eliminiranja dodatnih mjera osiguranja. Na izbor načina montaže bitno utječe i tehnološka opremljenost izvođača radova, kao i lokalni uvjeti na gradilištu.

\section{Literatura}

[1] Blanda, M.; Dolaček-Alduk, Z.; Mikulić, D. 2010: Upravljanje kvalitetom pri izvođenju betonskih konstrukcija, Građevinar 62, 7, 603-612

[2] Buđevac, D. 2000: Metalne konstrukcije u zgradarstvu, Građevinska knjiga, Beograd

[3] Ćurić, I. 2010: Dinamika uređenja gradilišta na primjeru izgradnje PTC Portanova u Osijek, završni rad, Sveučilište J. J. Strossmayera u Osijeku, Građevinski fakultet, Osijek

[4] Ćirović, G.; Mitrović, S. 2007: Tehnologija građenja, Visoka građevinsko-geodetska škola

[5] Folić, R.; Zenunović, D. 2009: Spregnute konstrukcije čelik-beton, Fakultet tehničkih nauka, Novi Sad

[6] Savić, M. 2010: Utjecaj odabira tehnologije građenja na izradu sheme uređenja gradilišta, završni rad, Sveučilište J. J. Strossmayera u Osijeku, Građevinski fakultet, Osijek

[7] Trbojević, B. 1992: Organizacija građevinskih radova, Naučna knjiga, Beograd 